\title{
FAKTOR-FAKTOR PENGHAMBAT ASEAN \\ INTERGOVERNMENTAL COMMISSION ON HUMAN RIGHTS \\ (AICHR) DALAM PENEGAKAN HAK ASASI MANUSIA DI ASIA \\ TENGGARA
}

Fiari Larasati Putri Irawan, Agus Subagyo, Jusmalia

Oktaviani

Abstract

ASEAN Intergovernmental Commission on Human Rights (AICHR) is an inter-governmental organization under the auspices of ASEAN, which focuses on human rights at the regional level. AICHR was established in 2009 and consists of 10 representatives from each ASEAN countries. Broadly speaking AICHR has two primary mandates which are function to promote and to perform protection against human rights.

The general objective of this research is to describe AICHR as a regional human rights commission, and the specific objectives of this research are to describe and analyze the Inhibiting factors of AICHR In Enforcement of Human Rights in Southeast Asia.

Researcher used qualitative research methods and descriptive analysis research type. The technique of collecting primary data was conducted through some interviews and secondary data collection techniques by literature study. Researcher applied the approach of Institutional Neoliberalism, the International Organization Theory, Regime Theory, and Concept of Human Rights as an analytical tool.

In this research it can be concluded that there are four inhibiting factors of the AICHR in Enforcement of Human Rights in Southeast Asia, including Principles of ASEAN Way which there are the principle of non-intervention and state sovereignty; Decision Making based on Consensus; Lack mandate of function to protection in the ToR of AICHR; and the last, there are Political Interests of Each Countries of ASEAN which includes Differing Views of Each ASEAN Countries against Human Rights and their Commitment to Human Rights.

Keywords : AICHR, Human Rights, Southeast Asia. 


\section{Dinamika Global | Volume 02 | No.01 | Juni 2017}

\section{Latar Belakang}

Pengertian hak asasi manusia sering dipahami sebagai hak kodrati yang dibawa oleh manusia sejak manusia lahir ke dunia (Bahder, 2011: 129). Hingga kurang lebih 60 tahun yang lalu, persoalan mengenai hak asasi manusia belum terlalu menjadi sorotan dunia. Pada masa itu, belum banyak negara yang memiliki pengaturan tentang hak asasi manusia, bahkan istilah tersebut masih jarang terdengar (Andrea et al, 2009:1).

Pembahasan mengenai pengertian dan konsep-konsep hak asasi manusia tidak dapat dilepaskan dari perkembangan instrumen hak asasi manusia yang memuatnya. Diawali dengan Deklarasi Universal Hak Asasi Manusia, sebuah deklarasi yang dirumuskan oleh PBB tahun 1948 merupakan dokumen hak asasi manusia tertulis pertama yang komprehensif, dihasilkan oleh semua negara-bangsa yang mewakili berbagai latar belakang budaya, kepercayaan, ideologi, dan orientasi politik (Bahder, 2011:131). Hal ini menjadi pedoman dasar bagi seluruh negara di dunia termasuk regional-regional untuk membuat badan independen yang membahas mengenai Hak Asasi Manusia.

Pasca perang dunia kedua, banyak terjadi pelanggaran atas hak asasi manusia. Oleh karena hal ini, komunitas internasional datang bersama-sama untuk menyatakan 'tidak akan pernah lagi' kekejaman seperti ini terulang bagi umat manusia (Drummond, 2010:5). Sayangnya, kejahatan genosida, perang,pembersihan etnis dan kejahatan terhadap kemanusiaan,masih terlalu dominan di awal-awal dekade abad kedua puluh satu. Komunitas internasional telah gagal untuk mencegahgenosida dankekejaman massal.Hal ini ditandai 


\section{Dinamika Global | Volume 02 | No.01 | Juni 2017}

dengan tragedi genosida di Rwanda dengan jumlah korban mencapai 800.000 jiwa (History, 2016)dan Srebrenica (pembantaian umat muslim di Bosnia \& Herzegovina) dengan jumlah korban mencapai 100.000 jiwa (Bosnia and Herzegovina, 2016).

Dimulai dari tahun 1945 saat Piagam PBB terbentuk, dalam ketentuan pasal 68, terdapat mandat yang diberikan PBB terhadap ECOSOC untuk membentuk suatu komisi guna mempromosikan hak asasi manusia. Berdasarkan hal tersebut perkembangan organisasi untuk menaungi hak asasi manusia dimulai. Sejak pertengahan tahun 1990, PBB dan organisasiorganisasi regional telah terlibat dalam proses bersama menjalin kemitraan yang lebih dekat untuk mengejar perdamaian dan keamanan. Setelah melewati berbagai diskusi tersebut, akhirnya munculah kesadaran akan pentingnya peranan di tingkat regional khususnya mengenai masalah HAM untuk membantu kinerja PBB serta membantu negara-negara yang membutuhkan untuk mewujudkan keadaan yang di inginkan oleh komunitas internasional. Oleh karena itu, mekanisme HAM regional dianggap sebagai cara yang tepat bagi ASEAN untuk mendukung mekanisme HAM yang telah dimiliki oleh PBB.

Secara perlahan, badan-badan di tingkat regional yang mengatur tentang Hak Asasi Manusia mulai bermunculan. Dimulai dengan diadopsinya The American Declaration of the Rights and Duties oleh Amerika di Bogota pada tahun 1948, The European Convention on Human Rights pada tahun 1949, serta 


\section{Dinamika Global | Volume 02 | No.01 | Juni 2017}

The African Charter on Human and Peoples" Rights pada tahun 1981 (Andrea et al, 2009:7). Perkembangan ini meninggalkan Asia, wilayah dengan kepadatan penduduk terbesar di dunia, sebagai satu-satunya regional yang tidak memiliki mekanisme HAM nya sendiri.

Akhirnya pada tahun 1993, Menteri Luar Negeri masingmasing negara anggota ASEAN menyinggung kemungkinan mendirikan mekanisme antar-pemerintah mengenai hak asasi manusia untuk regional sebagai berikut:"(Para Menteri Luar Negeri ASEAN) dalam mendukung Deklarasi Wina dan Program Aksi (dari Konferensi Dunia tentang Hak Asasi Manusia) sepakat bahwa ASEAN juga harus mempertimbangkan pembentukan mekanisme regional yang sesuai dengan hak asasi manusia." (Vitit, 2003).Dorongan untuk mengembangkan sistem regional antar-pemerintah untuk hak asasi manusia disediakan oleh World Conference on Human Rights (Konferensi Dunia untuk Hak Asasi Manusia) pada tahun 1993 berdasarkanadanya kebutuhan untuk mempertimbangkan kemungkinan membangun pengaturan regional dan subregional untuk promosi dan perlindungan hak asasi manusia. Karena semua negara ASEAN diwakili di Konferensi Dunia ini, mereka merupakan bagian dari momentum ini.

Perkembangan pembentukan badan HAM regional ini paling tidak mulai bisa dilihat dari pertemuan tingkat menteri ASEAN, yang berlangsung pada Juli 2008. Pertemuan ini menyepakatipembentukan High Level Panel on Establishment for ASEAN Human Rights Body, yang diberikan tugas untuk 


\section{Dinamika Global | Volume 02 | No.01 | Juni 2017}

menyusun bersama ToR ASEAN Human Rights Body dalam waktu 1 tahun sejak pembentukannya(Wahyudi et al, 2014:23). Awalnya, nama yang sempat diusulkan Indonesia untuk ASEAN Human Rights Bodyadalah ASEAN Commission on Human Rights, tidak memakai Intergovernmentalkarena keinginan atas sifatnya yang lebih mandiri. Akan tetapi kenyataannya karenanegosiasi politik yang memang lebih berperan, akhirnya yang disepakati ASEAN Intergovernmental Commission on Human Rights(Wahyudi et al, 2014:24).

Pada bulan Juli 2009, Kerangka Acuan (ToR AICHR) diresmikan oleh para Menteri Luar Negeri ASEAN dan akhirnya pada KTT ASEAN Ke-15 yang diselenggarakan di Thailand tanggal 23 Oktober 2009, AICHR resmi didirikan dengan disetujuinya the 'Cha-am Hua Hin Declaration onthe Inauguration of the AICHR' (Deklarasi Cha-am Hua Hin tentang Peresmian AICHR)(Wahyudi et al, 2014:24). AICHR sesuai dengan mandatnya yang tercantum dalam kerangka acuan memiliki dua fungsi utama, yakni fungsi promosi, dan fungsi proteksi.Terms of Reference of the ASEAN Intergovernmental Commission on Human Rights, Mandate and Functions, Pasal 4(1) menyatakan: "To develop strategies for the promotion and protection of human rights and fundamental freedoms to complement the building of the ASEAN Community;"Michael (2009:2) menyebutkan bahwa AICHR juga pada saat ini memegang beberapa peranan, diantaranya sebagai lembaga penasihat, koordinasi dan konsultasi HAM. Di masa yang akan 


\section{Dinamika Global | Volume 02 | No.01 | Juni 2017}

datang, AICHR diharapkan dapat menjadi badan yang berperan dalam mereformasi Hak Asasi Manusia di Asia Tenggara.

Kenyataannya, setelah AICHR berdiri sejak Oktober 2009, AICHR terlihat belum menjalankan fungsi proteksi mereka sebagai badan hak asasi manusia di tingkat regional. Masih terdapat kasus-kasus pelanggaran HAM yang terjadi di Asia Tenggara, namun AICHR seolah-olah tidak menunjukkan keberadaanya karena terlihat pasif. AICHR tidak mempunyai mekanisme dalam menangani kasus-kasus ataupun untuk menerima pengaduan pelanggaran HAM dari masyarakat (The Jakarta Post, 2010).

Hingga menjelang berakhirnya periode AICHR pertama pada 2012, tidak ada respon apapun dari AICHR terhadap beberapa kasus yang dilaporkan seperti contohnya pengungsi Rakhine Myanmar, pembantaian Maguindanao di Filipina, penangkapan 1500 orang dalam gerakan BERSIH Malaysia, dan penangkapan puluhan aktifis di Kamboja. AICHR berpandangan bahwa mereka tidak bisa mencampuri hal-hal yang dipandang sebagai urusan internal dalam negeri pemerintah tiap-tiap negara anggota ASEAN (Kanis, 2016). Menurut Wahyudi et al. (2014:24), fakta demikian menjadikan badan HAM ASEAN masih bersifat semu. Negaranegaraanggota ASEAN belum menerima secara penuh badan HAM ASEAN sebagai badan yang dapat memproteksi HAM bagi rakyat negara-negara anggota ASEAN. 


\section{Dinamika Global | Volume 02 | No.01 | Juni 2017}

Hal ini semakin memperkuat bukti mengenai belum optimalnya AICHR untuk mengatasi isu-isu pelanggaran HAM di Asia Tenggara. Fakta-fakta tersebut, akhirnya mendorong peneliti untuk menjelaskan mengenai faktor-faktor penghambat AICHR dalam menjalankan mandat dan fungsinya sebagai badan penaung HAM di Asia Tenggara.

Berdasarkan uraian yang telah dipaparkan sebelumnya, maka peneliti merumuskan masalah penelitian sebagai berikut:“Apa saja Faktor-faktor Penghambat ASEAN Intergovernmental Commission on Human Rights (AICHR) dalam Penegakan Hak Asasi Manusia di Asia Tenggar 


\section{Dinamika Global | Volume 02 | No.01 | Juni 2017}

Kerangka Teoritis

Kerangka teori yang relevan dengan penelitian ini adalah Pendekatan Neoliberalisme Institusional, Teori Organisasi Internasional, Regime Theory, dan Konsep Hak Asasi Manusia.

1. Neoliberalisme Institusional

Robert O. Keohane (1984:8) menyatakan, neoliberalisme institusional percaya bahwa institusi internasional sangat berperan dalam mewujudkan kerjasama. Perspektif ini tidak melihat institusi pada sebatas organisasi formal yang memiliki kantor utama dan staf terspesialisasi, tetapi lebih luas. Institusi mampu mempengaruhi perilaku negara. Sterling Foker menuturkan bahwakaum neoliberalisme menganggap bahwa dengan adanya kerjasama antar negara maka akan tercipta kepentingan nasional yang sama oleh masing-masing negara yang bekerjasama (2013:129).

Seiring dengan banyaknya kaum neoliberalismeyang menerima karakterisasi neorealis dari anarkissistem internasional, dengan kesamaan national interest maka setiap negara akan cenderung untuk terus menerus bekerja sama, hal tersebut menciptakan kondisi yang kondusif karena konflik akan relatif berkurang dibandingkan apabila negara tidak bekerja sama dan kemudian masing-masing pihak akan mendapatkan keuntungan (Lamy dalam Baylis dan Smith, 2001: 190). Neoliberalismeinstitusional menggunakan kerjasama yang dilakukan oleh negara-negara dengan kemampuan lembaga-lembaga internasional dan rezim untuk mengurangi dampak dari anarki.

Institusi internasional digambarkan oleh neoliberal sebagai sebuah wadah dimana aturan (baik formal maupun informal) 
menentukan perilaku, membatasi kegiatan dan membentuk harapan terhadap kerjasama diantara negara-negara yang ada di dalamnya. Kondisi tersebut karena institusi memiliki prinsip, norma, peraturan, dan prosedur, yang kemudian disebut sebagai rezim yang menjadi pedoman bagi aktor dalam bertindak. Dengan demikian, rezim mengurangi dampak anarki (Keohane, 1984: 84)Institusi akan membantu mengatur sistem yang kompetitif dan anarkis dan mendorong untuk membentuk kerjasama sebagai cara untuk mengamankan kepentingan nasionalnya.

2. Organisasi Internasional

Organisasi Internasional secara sederhana dapat didefinisikan sebagai pengaturan bentuk kerjasama internasional yang melembaga antara negara-negara, umumnya berlandaskan suatu persetujuan dasar, untuk melaksanakan fungsi-fungsi yang memberi manfaat timbal balik yang diejawantahkan melalui pertemuan-pertemuan serta kegiatan-kegiatan staf secara berkala (Teuku, 2009:2).

Organisasi-organisasi internasional tumbuh karena adanya kebutuhan dan kepentingan masyarakat antar-bangsa untuk adanya wadah serta alat untuk melaksanakan kerjasama internasional. L. Leonard dalamTeuku (2009: 4) mengemukakan pendapatnya bahwa: "Negara-negara berdaulat menyadari perlunya pengembangan cara/metode kerjasama berkesinambungan yang lebih baik mengenai penanggulangan untuk memenuhi kebutuhan-kebutuhan tersebut."

3. Regime Theory

Krasner mendefinisikan tentang rezim, ia berpendapat bahwa rezim merupakan prinsip, norma, aturan, dan prosedur pengambilan keputusan baik implisit maupun eksplisit yang diharapkan hadir untuk mengatur perilaku aktor atas isu-isu tertentu dalam hubungan internasional. Sehingga rezim secara umumnya adalah segala perilaku aktor-aktor hubungan internasional yang 


\section{Dinamika Global | Volume 02 | No.01 | Juni 2017}

mengandung prinsip, norma serta aturan di dalamnya. Perilaku ini dapat menghasilkan kerjasama dan melalui institusilah rezim bisa berjalan (Rizka, 2014). Rezim mengacu pada pengaruh perilaku yang ditimbulkan dari organisasi internasional pada aktor-aktor yang lainnya, terutama aktor negara.

Ada beberapa pengamatan saat ini tentang definisi rezim. Yang pertama adalah bahwa isu dalam rezim adalah masalah yang spesifik; yang kedua adalah bahwa analisis rezim menentukan berbagai hal untuk dilihat, seperti prinsip-prinsip, norma dan aturan, sertaprosedur pengambilan keputusan. Analisis rezim memungkinkan kita untuk mempertanyakan berasal dari manakah organisasi internasional dan seberapa efektif mereka (Rizka, 2014:37).Efektivitas sebuah rezim secara langsung diukur dengan tingkat kepatuhan dengan aturan oleh negara-negara (Keohane, 1984:84).

4. Konsep Hak Asasi Manusia

Masyarakat internasional menegaskan konsep holistik mengenai hak asasi manusia pada Konferensi Dunia tentang Hak Asasi Manusia, yang diselenggarakan di Wina pada tahun 1993 (World Conference on Human Rights, Vienna 1993), sebagai:

"Semua hak asasi manusia bersifat universal, tak terpisahkan dan saling tergantung dan saling terkait.Masyarakat internasional harus memperlakukan hak asasi manusia secara global dengan cara yang adil dan setara, pada pijakan yang sama, dan dengan penekanan yang sama. Sementara signifikansinasional dan kekhasan daerah dan berbagai sejarah, budaya danlatar belakang agama harus diingat karena itu adalah tugas negara, terlepas darisistem politik, ekonomi dan budaya mereka, untuk mempromosikan dan 
melindungi semua manusiahak dan kebebasan fundamental (Vienna Declaration, 16)."

Mengenai banyaknya jenis pelanggaran HAM yang masih terjadi di banyak negara saat ini, Rome Statute pasal 5 memberikan penjelasan mengenai klasifikasi untuk pelanggaran HAM berat, yakni yang terbatas pada kejahatan yang paling serius yang menjadi perhatianuntuk masyarakat internasional secara keseluruhan, diantaranya:

a. Kejahatan genosida;

b. Kejahatan terhadap kemanusiaan;

c. Kejahatan perang;

d. Kejahatan agresi.

'Genosida' berarti salah satu tindakan yang dilakukan dengan maksud untuk menghancurkansecara keseluruhan atau sebagian, nasional, etnis, ras ataukelompok agama, seperti:

a. Membunuh anggota kelompok;

b. Mengakibatkan penderitaan fisik dan mental yang berat terhadap anggota-anggota kelompok;

c. Menciptakan kondisi kehidupan kelompok yang akan mengakibatkan kemusnahan secara fisik baik seluruh atau sebagiannya;

d. Memaksakan tindakan-tindakan yang bertujuan mencegah kelahiran di dalam kelompok; atau

e. Memindahkan secara paksa anak-anak dari kelompok tertentu ke kelompok lain.

'Kejahatan terhadap Kemanusiaan' berarti perbuatan yang dilakukan sebagai bagian dari serangan yang meluas atau 
sistematik yang diketahuinya bahwa serangan tersebut ditujukan secara langsung terhadap penduduk sipil, berupa:

a. Pembunuhan;

b. Pemusnahan;

c. Perbudakan;

d. Pengusiran atau pemindahan penduduk secara paksa;

e. Perampasan kemerdekaan atau perampasan kebebasan fisik lain secara sewenang-wenang yang melanggar (asas-asas) ketentuan pokok hukum internasional;

f. Penyiksaan;

g. Perkosaan, perbudakan seksual, pelacuran secara paksa, pemaksaan kehamilan, pemandulan atau sterilisasi secara paksa atau bentuk-bentuk kekerasan seksual lain yang setara;

h. Penganiayaan terhadap suatu kelompok tertentu atau perkumpulan yang didasari persamaan paham politik, ras, kebangsaan, etnis, budaya, agama, jenis kelamin atau alasan lain yang telah diakui secara universal sebagai hal yang dilarang menurut hukum internasional;

i. Penghilangan orang secara paksa; atau

j. Kejahatan apartheid

k. Tindakan tidak manusiawi lainnya yang bersifat sama yang secara sengaja menyebabkan penderitaan besar, atau cedera serius terhadap badan atau mental atau kesehatan fisik.

Alasan peneliti mengambil konsep HAM ini bertujuan untuk menunjukkan bahwa pelanggaran HAM yang terjadi di Asia Tenggara cenderung masuk dalam kategori pelanggaran HAM berat. Hal ini dapat dilihat dari paparan singkat mengenai kasus pelanggaran HAM yang di paparkan di latar belakang 


\section{Dinamika Global | Volume 02 | No.01 | Juni 2017}

yang terdiri dari penangkapan \& penahanan, penyiksaan, pembunuhan, hingga pembantaian.

Gambaran Umum ASEAN Intergovernmental Commission on Human Rights (AICHR)

ASEAN Intergovernmental Commission on Human Rights(AICHR) didirikan pada tahun 2009. AICHR adalahbadan menyeluruh dengan mandat lintas sektoral yang menangani hal-hal yang berkaitan dengan kerjasama hak asasi manusia dengan badan ASEAN lainnya, mitra eksternal sertastakeholder.Pasal 14 ASEAN Charter menyatakan bahwa "Sesuai dengan tujuan dan prinsip Piagam ASEAN yang berkaitan dengan promosi dan perlindungan hak asasi manusia dan kebebasan fundamental, ASEAN akan membentuk badan hak asasi manusia ASEAN". Hal ini menjadi landasan konstitusional dari terbentuknya Komisi HAM Antar-Pemerintah ASEAN (AICHR).

Sebelum diresmikan, Kerangka Acuan (Terms of Reference) AICHR di diadopsi di KTT ASEAN ke-14 di Phuket, Thailand pada tanggal 20 Juli 2009. Akhirnya, pada 23 oktober 2009, AICHR diresmikan pada saat KTT ASEAN ke 15 tanggal 23 Oktober 2009 di Hua Hin, Thailand dengan sepuluh perwakilan yang ditunjuk dari masing-masing negara anggota ASEAN untuk AICHR. AICHR juga menyelenggarakan pertemuan regular 2 kali dalam setahun dan pertemuan tambahan jika diperlukan kemudian melaporkannya ke masing-masing Menteri Luar Negeri negara ASEAN.

AICHR merupakan institusi penaung (overarching) hak asasi manusia di ASEAN dengan tanggung jawab secara umum adalah untuk pemajuan dan perlindungan HAM di wilayah ASEAN. AICHR memiliki tujuan, mandat dan fungsi utama untuk melakukan 


\section{Dinamika Global | Volume 02 | No.01 | Juni 2017}

promosi dan proteksi atas hak asasi manusia di Asia Tenggara. AICHR terdiri dari wakil-wakil dari 10 negara Anggota ASEAN yang bertanggung jawab kepada pemerintah yang menunjuknya. Saat ini dari 10 perwakilan dari AICHR, 3 perwakilan dipilih dari kalangan Organisasi Masyarakat Sipil (CSO) yakni dari Indonesia, Thailand, dan Malaysia. sementara yang lainnya dari perwakilan yang ditunjuk oleh Pemerintah. Setiap wakil menjabat untuk satu kali masa jabatan selama 3 tahun dan setelahnya dapat diangkat kembali hanya untuk satu kali masa jabatan. Sebagai organisasi penaung di ASEAN, AICHR bekerja dengan dengan seluruh badan-badan sektoral ASEAN didalam 3 ASEAN pilar yakni, Pilar Politik dan Keamanan ASEAN, Pilar Ekonomi ASEAN, dan Pilar Sosial Budaya ASEAN.

Gambaran Umum Pelanggaran dan Penegakan Hak Asasi Manusia di Asia Tenggara

Dalam pembahasan sehari-hari di media cetak maupun elektronik, seringkali muncul masalah-masalah HAM berat di kawasan ASEAN. Misalnya dalam bentuk kejahatan berat terhadap kemanusiaan (crimes on humanity) baik itu yang terjadi di Indonesia, Kamboja, Filipina dan negara-negara anggota ASEAN lainnya. Di Kamboja tidak ada pengadilan untuk pelanggaran ataupun kejahatan HAM. Di Myanmar terdapat indikasi yang kuat terjadinya kejahatan terhadap kemanusiaan, yaitu sesuai hasil laporan terakhir dari Pelapor Khusus PBB untuk Myanmar yang disampaikan di Jenewa, mengenai persoalan genosida dan penyiksaan, yang tergolong sebagai pelanggaran HAM berat (Tabloit Diplomasi, 2010).

Masih menurut Tabloit Diplomacy, Lalu masalah pengadilan di luar koridor hukum yang sering terjadi di Mindanau, Filipina, dikarenakan terjadinya konflik politik lokal yang mengakibatkan lumpuhnya proses penegakan hukum. Berikutnya adalah masalah 


\section{Dinamika Global | Volume 02 | No.01 | Juni 2017}

diskriminasi yang terkait dengan ras, kebebasan beragama, suku, asal-usul, serta gender. Kemudian masalah pelaksanaan hukuman mati, yang dimana seluruh negara ASEAN masih menerapkan hukuman mati, kecuali Filipina. Masalah lainnya yang sering diberitakan di media cetak adalah apa yang disebut sebagai perdagangan manusia (trafficking in person), yang erat kaitannya dengan diskriminasi, perlindungan HAM terhadap pengungsi, baik yang disebabkan karena konflik bersenjata ataupun karena bencana alam.

Berdasarkan gambaran umum singkat diatas, berikut peneliti mengulas secara singkat gambaran mengenai pelanggaran dan penegakan hak asasi manusia di 10 negara anggota ASEAN yang didasarkan pada beberapa kasus pelanggaran HAM yang pernah dilaporkan kepada AICHR sejak tahun 2009 ketika AICHR dibentuk sampai tahun 2015. Selain kasus pelanggaran HAM yang dilaporkan pada AICHR, peneliti juga mengangkat beberapa kasus pelanggaran HAM yang dominan terjadi di negara yang bersangkutan. 


\section{Dinamika Global | Volume 02 | No.01 | Juni 2017}

Tabel: Pelanggaran HAM di Asia Tenggara dari tahun 20092015

\begin{tabular}{|c|c|c|c|c|}
\hline No. & Negara & Tahun & Kasus & Respon AICHR \\
\hline 1. & $\begin{array}{l}\text { Brunei } \\
\text { Darussala } \\
\mathrm{m}\end{array}$ & 2014 & $\begin{array}{l}\text { Penerapan } \\
\text { hukum } \\
\text { syariah Islam }\end{array}$ & $\begin{array}{l}\text { AICHR tidak } \\
\text { memberikan } \\
\text { respon atas } \\
\text { kasus ini }\end{array}$ \\
\hline 2. & Filipina & 2009 & $\begin{array}{l}\text { Pembantaian } \\
\text { Maguindanao }\end{array}$ & $\begin{array}{l}\text { AICHR tidak } \\
\text { bertindak atas } \\
\text { kasus ini }\end{array}$ \\
\hline 3. & Indonesia & 2015 & $\begin{array}{l}\text { Perbudakan } \\
\text { nelayan di } \\
\text { Benjina, } \\
\text { Kepulauan } \\
\text { Aru }\end{array}$ & $\begin{array}{l}\text { AICHR tidak } \\
\text { memberikan } \\
\text { respon atas } \\
\text { kasus ini }\end{array}$ \\
\hline 4. & Kamboja & 2009 & $\begin{array}{c}\text { Perdagangan } \\
\text { Manusia }\end{array}$ & $\begin{array}{l}\text { AICHR tidak } \\
\text { memberikan } \\
\text { respon atas } \\
\text { kasus ini }\end{array}$ \\
\hline 5. & Laos & 2012 & $\begin{array}{l}\text { Penghilangan } \\
\text { paksa aktivis } \\
\text { Laos }\end{array}$ & $\begin{array}{l}\text { AICHR tidak } \\
\text { memberikan } \\
\text { respon atas } \\
\text { kasus ini }\end{array}$ \\
\hline 6. & Malaysia & 2011 & $\begin{array}{l}\text { Aksi "BERSIH" } \\
\text { untuk Pemilu } \\
2012 \text { yang adil }\end{array}$ & $\begin{array}{l}\text { AICHR tidak } \\
\text { memberikan } \\
\text { respon atas } \\
\text { kasus ini }\end{array}$ \\
\hline 7. & Myanmar & 2012 & $\begin{array}{l}\text { Pengungsi } \\
\text { Rohingya }\end{array}$ & $\begin{array}{l}\text { AICHR melakukan } \\
\text { Retreat dengan } \\
\text { Myanmar }\end{array}$ \\
\hline
\end{tabular}




\begin{tabular}{|c|c|c|l|l|}
\hline 8. & Singapura & 2012 & $\begin{array}{l}\text { Mogok kerja } \\
\text { pekerja } \\
\text { migran dari } \\
\text { Tiongkok }\end{array}$ & $\begin{array}{c}\text { AICHR tidak } \\
\text { memberikan } \\
\text { respon atas } \\
\text { kasus ini }\end{array}$ \\
\hline 9. & Thailand & 2011 & $\begin{array}{l}\text { Penahanan } \\
\text { aktivis politik }\end{array}$ & $\begin{array}{c}\text { AICHR tidak } \\
\text { memberikan } \\
\text { respon atas } \\
\text { kasus ini }\end{array}$ \\
\hline 10. & Vietnam & 2014 & $\begin{array}{c}\text { Penangkapan \& } \\
\text { penahanan } \\
\text { aktivis }\end{array}$ & $\begin{array}{c}\text { AICHR tidak } \\
\text { memberikan } \\
\text { respon atas } \\
\text { kasus ini }\end{array}$ \\
\hline
\end{tabular}

Sumber: Hasil pengolahan peneliti

Dari gambaran umum tabel mengenai pelanggaran hak asasi manusia di Asia Tenggara diatas dapat disimpulkan bahwa AICHR sebagai komisi HAM regional belum bisa sepenuhnya melakukan perlindungan terhadap permasalahan HAM yang terjadi sejak dibentuknya AICHR tahun 2009. Dapat disimpulkan dari beberapa kasus yang dilaporkan ke AICHR sejak 2009-2015, terlihat bahwa AICHR secara dominan tidak memberikan respon terhadap isu-isu tersebut. AICHR hanya bertindak untuk kasus Rohingya, namun itupun hanya melakukan retreat (konsultasi dan diskusi) dengan Myanmar. Sisanya, AICHR hanya melakukan workshop untuk mendiskusikan kasus pelanggaran HAM yang terjadi di tingkat regional dan penegakan terhadap masing-masing pelanggaran HAM yang terjadi secara dominan dilakukan oleh aktor dalam negeri masing-masing negara ASEAN. 


\section{Dinamika Global | Volume 02 | No.01 | Juni 2017}

Faktor-faktor Penghambat ASEAN Intergovernmental Commission on Human Rights (AICHR) dalam Penegakan Hak Asasi Manusia di Asia Tenggara

Berdasarkan hasil penelitian, berikut peneliti akan memaparkan mengenai faktor-faktor penghambat AICHR dalam penegakan hak asasi manusia di Asia Tenggara, yang terdiri dari empat hambatan diantaranya: Prinsip ASEAN Way; Pengambilan Keputusan Berdasarkan Konsensus; Lemahnya Mandat Fungsi Proteksi Dalam ToR AICHR; dan terakhir Terdapat Kepentingan Politik dari Masing-masing Negara ASEANyang didalamnya mencakup Perbedaan Pandangan Masing-masing Negara ASEAN Terhadap HAM serta Kurangnya Komitmen Masing-masing Negara ASEAN Terhadap HAM.

Prinsip ASEAN Way

ASEAN Way merupakan suatu pendekatan negara-negara di Asia Tenggara terhadap kerjasama politik dan keamanan. Biasanya ASEAN Way mengacu pada cara pengambilan keputusan, tetapi beberapa ahli mendefinisikannya lebih sebagai sebuah norma dan gaya hidup negara-negara ASEAN. Lebih lanjut, Amitav Acharya (63) menyatakan bahwa ASEAN Way adalah sebuah bentuk yang dibuat oleh para pemimpin ASEAN itu sendiri untuk menjelaskan suatu proses interaksi intra-mural untuk membedakan antara satu dengan yang lainnya, terutama negara barat, tata cara multilateral. Tetapi 


\section{Dinamika Global | Volume 02 | No.01 | Juni 2017}

tidak ada definisi yang resmi mengenai ASEAN Way. ASEAN Way adalah konsep yang digunakan secara bebas yang serta memiliki arti yang tidak pasti.

Mengapa ASEAN Way ini dikatakan sebagai penghambat karena hal ini berkaitan dengan ketidakmampuan AICHR untuk melakukan fungsi proteksi secara langsung pada segala permasalahan HAM yang berimplikasi regional yang membuat eksistensi dan independensi AICHR menjadi sangat dipertanyakan. Hal ini dikarenakan adanya prinsip nonintervensi dan kedaulatan dari sebuah negara yang membatasi kinerja AICHR sebagai sebuah komisi HAM regional. HAM merupakan sesuatu yang universal yang seharusnya bukan menjadi suatu alasan dan ketakutan bagi sebuah negara untuk menutup dirinya demi bantuan kemanusiaan.

Selain itu, mengapa prinsip non-intervensi dan kedaulatan yang terdapat dalam ASEANWay dikatakan menghambat karena hal ini tidak sejalan dengan prinsip/norma R2P (Responsibility to Protect) yang menyatakan bahwa kedaulatan sebuah negara bukanlah hak mutlak dan negara kehilangan sebagian kedaulatannya apabila negara gagal melindungi penduduknya dari kejahatan dan pelanggaran HAM berat (genosida, kejahatan terhadap kemanusiaan, kejahatan perang, dan pembersihan etnis) seperti yang sudah di paparkan dalam Majelis Umum PBB (United Nations, 2005: 138-40). R2P juga memiliki tiga pilar diantaranya: 


\section{Dinamika Global | Volume 02 | No.01 | Juni 2017}

1. Sebuah negara bertanggung jawab melindungi penduduknya dari genosida, kejahatan terhadap kemanusiaan, kejahatan perang, dan pembersihan etnis.

2. Masyarakat internasional bertanggung jawab membantu negara memenuhi tanggung jawab utamanya.

3. Apabila negara gagal melindungi warganya dari empat tindak kekerasan di atas dan gagal menegakkan perdamaian, masyarakat internasional bertanggung jawab untuk campur tangan lewat tindakan koersif seperti sanksi militer. Intervensi militer dianggap sebagai pilihan terakhir (Global Centre for the Responsibility to Protect, 2017).

Pengambilan Keputusan Berdasarkan Konsensus

Dalam prosesnya, negosiasi dan konsensus ini terjadi diantara para perwakilan AICHR masing-masing negara anggota ASEAN, karena AICHR itu diwakili oleh wakil negara. Alasan mengapa pengambilan keputusan melalui konsensus menjadi penghambat adalah karena keputusan yang diambil harus secara bulat. Sebagai contoh ketika AICHR sedang mengangkat sebuah tema atau isu untuk dibahas, kemudian terdapat satu negara saja yang menyatakan tidak setuju akan hal tersebut dengan satu atau lain hal, maka konsensus tidak akan terwujud. Padahal disisi lain, bisa saja isu tersebut sedang menjadi sebuah urgensi di satu atau beberapa negara dan dibutuhkan suatu penyelesaian dengan segera.

Sebagai contoh ketika Indonesia sudah pernah menawarkan agar AICHR mempunyai 3 mandat untuk melakukan fungsi proteksi yang diantaranya: wewenang 
menerima pengaduan individual, wewenang untuk investigasi, dan wewenang untuk country visit, tetapi di tolak dan tidak mencapai konsensus pada Rapat Menteri Luar Negeri ASEAN ke-43 Menteri (AMM) pada bulan Juli 2010. ${ }^{1}$ Fungsi individual complain serta pembahasan situasi HAM di negara-negara anggota ditolak dengan alasan bahwa hal tersebut sudah dilakukan oleh lembaga review tingkat dunia, atau sudah dilakukan secara universal, maka tidak perlu lagi untuk dibahas di tingkat ASEAN. Pengajuan fungsi proteksi AICHR untuk country situation juga ditolak oleh 9 negara ASEAN yang lain yang menurut Indonesia bukan dalam konteks promosi, melainkan investigasi untuk pencarian fakta. Tiga fungsi proteksi tersebut telah dicoba untuk diperjuangkan tetapi belum berhasil lolos konsensus.

Lemahnya Mandat Fungsi Proteksi Dalam Term of Reference (ToR) AICHR

Terkait dengan lemahnya mandate fungsi proteksi dalam ToR AICHR, AICHR belum memiliki mekanisme proteksi yang diantaranya: tidak ada wewenang menerima pengaduan individual/kelompok, wewenang untuk investigasi, dan wewenang untuk country visit. Ibu Dinna Wisnu selaku Wakil Indonesia untuk AICHR periode 2016-2018 menambahkan penjelasan mengenai AICHR yang belum bisa untuk menciptakan 3 mandat fungsi proteksi dasar tersebut di situasi seperti sekarang, karena negara-negara ASEAN yang lain politik

\footnotetext{
${ }^{1}$ Hasil wawancara dengan Bapak Rafendi Djamin, di Coffee Club Plaza Senayan pada tanggal 02 Januari 2017 pukul 14.30 - 15.45, pedoman wawancara no.2
} 


\section{Dinamika Global | Volume 02 | No.01 | Juni 2017}

dalam negerinya menuntut mereka untuk inward looking melihat kedalam negeri masing-masing, berbeda dengan tahun 1960 atau 1990an, politik dalam negeri negara-negara ASEAN semuanya melihat keluar karena untuk melihat globalisasi dan kerjasama regional. Namun sekarang semuanya melihat kedalam, untuk meningkatkan produksi dalam negeri dan pasar dalam negeri. Bapak Rafendi Djamin juga menambahkan penjelasan terkait mandat untuk melakukan pengaduan individual/kelompok sebagai fungsi proteksi dari AICHR. Secara resmi AICHR memang tidak bisa melakukan satu pembahasan berdasarkan satu laporan. Hambatan lain yang terkait dengan mandat untuk melakukan fungsi perlindungan adalah, AICHR tidak dapat menjatuhkan sanksi, dan pembahasan HAM hanya dilakukan melalui dialog.

Terdapat Kepentingan Politik Dari Masing-masing Negara ASEAN

Perlu diketahui bahwa AICHR merupakan lembaga politik, lebih kepada lembaga politik karena yang terjadi dalam AICHR adalah negosiasi-negosiasi politik. Walaupun fokusnya mengenai HAM, tetapi dalam pelaksanannya AICHR selalu berat dengan kepentingan-kepentingan politik dari masingmasing negara. Contoh dari kepentingan politik yang terjadi dalam AICHR misalnya adalahKamboja dan Laos yang dimana mereka pasti tidak mau membicarakan permasalahan antitorture (anti penyiksaan) atau segala hal yang nantinya mengarah kepada rezimnya mereka ketika zaman Pol pot, dan 


\section{Dinamika Global | Volume 02 | No.01 | Juni 2017}

itu akan rumit. Kepentingan politik dari masing-masing negara anggota ASEAN juga terlihat ketika proses pembuatan kebijakan terhadap setiap isu atau tema yang sedang dibahas oleh AICHR. Hal ini dapat dilihat ketika Menteri Luar Negeri ASEAN merumuskan suatu kebijakan akan tetapi tidak lolos konsensus dikarenakan satu atau dua negara merasa bahwa isu yang sedang diangkat bukanlah isu prioritas di negara mereka sehingga mereka tidak meloloskan konsensus dan memilih untuk mengangkat isu yang menjadi prioritas di negara mereka.

Perbedaan Pandangan Masing-Masing Negara ASEAN Terhadap HAM

Cara pandang negara-negara ASEAN terhadap HAM masih sangat beragam. Hal ini tidak terlepas dari beragamnya kondisi sosial politik masing-masing negara anggota. Selain itu, di antara negara-negara ASEAN juga terdapat perbedaan interpretasi HAM antara universalis vs. partikularis (Lidya, 2014).Sementara itu, Bauer (1995) mengatakan, adanya perbedaan pandangan dari masing-masing negara anggota ASEAN terhadap hak asasi manusia ini dipengaruhi oleh beberapa hal:

1. Keragaman yang begitu kental di kawasan tersebut sehingga sulit untuk menetapkan standar umum mengenai hak asasi manusia;

2. Prioritas negara-negara dalam membangun bangsanya masingmasing serta memberantas kemiskinan; 


\section{Dinamika Global | Volume 02 | No.01 | Juni 2017}

3. Masih adanya pemerintahan otoriter pada beberapa negara di Asia Tenggara

Tabel 4.1: Pandangan Negara-negara ASEAN Terhadap HAM

\begin{tabular}{|c|c|c|}
\hline No. & Negara & Pandangan Terhadap HAM \\
\hline 1. & $\begin{array}{l}\text { Brunei } \\
\text { Darussalam }\end{array}$ & $\begin{array}{l}\text { Cenderung memandang HAM sebagai } \\
\text { urusan dalam negeri dan menerapkan } \\
\text { sistem hukum syariah islam }\end{array}$ \\
\hline 2. & Filipina & $\begin{array}{c}\text { Cenderung memandang HAM sebagai } \\
\text { urusan dalam negeri namun sudah } \\
\text { lebih progresif (sudah punya komnas } \\
\text { HAM) }\end{array}$ \\
\hline 3. & Indonesia & $\begin{array}{c}\text { Lebih terbuka dan progresif mengenai } \\
\text { HAM (perwakilan AICHR yang dipilih } \\
\text { dari non-pemerintah) }\end{array}$ \\
\hline 4. & Kamboja & $\begin{array}{l}\text { Cenderung memandang HAM sebagai } \\
\text { urusan dalam negeri }\end{array}$ \\
\hline 5. & Laos & $\begin{array}{c}\text { Cenderung memandang HAM sebagai } \\
\text { urusan dalam negeri }\end{array}$ \\
\hline 6. & Malaysia & $\begin{array}{l}\text { Lebih terbuka dan progresif mengenai } \\
\text { HAM (perwakilan AICHR yang dipilih } \\
\text { dari non-pemerintah) }\end{array}$ \\
\hline 7. & Myanmar & $\begin{array}{l}\text { Cenderung memandang HAM sebagai } \\
\text { urusan dalam negeri namun sudah } \\
\text { mulai progresif (telah mendirikan } \\
\text { Komnas HAM tahun 2011) }\end{array}$ \\
\hline 8. & Singapura & $\begin{array}{l}\text { Cenderung memandang HAM sebagai } \\
\text { urusan dalam negeri yang dapat } \\
\text { diselesaikan melalui peradilan }\end{array}$ \\
\hline 9. & Thailand & $\begin{array}{l}\text { Sudah lebih terbuka dan progresif } \\
\text { mengenai HAM (perwakilan AICHR } \\
\text { yang dipilih dari non-pemerintah) }\end{array}$ \\
\hline 10. & Vietnam & $\begin{array}{c}\text { Cenderung memandang HAM sebagai } \\
\text { urusan dalam negeri }\end{array}$ \\
\hline
\end{tabular}

Sumber: Hasil pengolahan peneliti 


\section{Dinamika Global | Volume 02 | No.01 | Juni 2017}

Kurangnya Komitmen dari Masing-masing Negara ASEAN terhadap HAM.

Secara umum negara-negara ASEAN masih cenderung ambigu terkait komitmen mereka terhadap HAM dan melihat hal ini sebagai sesuatu yang sensitif atau bersinggungan dengan kedaulatan (Lidya, 2014).Hal ini ditandai dengan belum adanya desakan dari AICHR kepada Negara-negara anggota ASEAN untuk meratifikasi instrumen HAM internasional seperti Kovenan Internasional mengenai Hak Sipil dan Politik (ICCPR) dan Kovenan Internasional mengenai Hak Ekonomi Sosial dan Budaya (ICESCR) yang merupakan dua instrumen yang cukup penting dalam perlindungan HAM. Singapura, Malaysia, Brunei Darussalam dan Myanmar masih belum menandatangani baik ICCPR maupun ICESCR (INFID, 2014).

Meskipun begitu, ASEAN dan AICHR juga telah banyak meratifikasi beberapa konvensi internasional, namun implementasi atau pelaksanaan dari beberapa konvensi yang telah di ratifikasi tersebut masih sedikit dipertayakan karena komitmen dari negara-negara anggota ASEAN terhadap hak asasi manusia ini tidak bisa terlepas dari ASEAN dan AICHR yang bersifat antar-pemerintah (intergovernmental) yang menjadikan wewenangnya sebagai badan HAM regional sangat dibatasi dan secara substansi lebih bertanggung jawab kepada negara anggota (Lidya, 2014).

Komitmen juga terkait dengan perwakilan masing-masing negara untuk AICHR yang maih secara resmi ditunjuk oleh pemerintah. Hingga saat ini baru Indonesia, Thailand, dan 


\section{Dinamika Global | Volume 02 | No.01 | Juni 2017}

Malaysia yang perwakilannya berasal dari masyarakat sipil. Hal ini penting untuk menunjuk perwakilan AICHR dari masyarakat sipil/CSO agar perwakilan AICHR tidak hanya menyuarakan suara dan kepentingan pemerintahnya saja (Lidya, 2014). Sehingga, komitmen dari masing-masing negara anggota ASEAN tentunya akan sangat menentukan pada independensi dari AICHR itu sendiri yang dimana jika AICHR sudah lebih independen, tentunya akan memudahkan AICHR untuk melaksanakan fungsi dan mandatnya dalam penegakan dan perlindungan HAM secara optimal tanpa harus banyak tercampur oleh kepentingan politik masing-masing negara ASEAN.

Kesimpulan

Dibentuknya ASEAN Intergovernmental Commission on Human Rights (AICHR) sejak tahun 2009 merupakan sebuah prestasi tersendiri bagi ASEAN dan hadirnya AICHR memang sangat diperlukan mengingat Asia Tenggara merupakan salah satu kawasan yang memiliki banyak sekali kasus pelanggaran HAM. AICHR sudah melakukan fungsi promosinya dengan baik untuk secara perlahan mendorong negara-negara ASEAN menyadari pentingnya melakukan perlindungan HAM, seperti misalnya rutin mengadakan workshop atau training dan dialog dengan kementerian terkait dan para media. AICHR juga sudah mencoba untuk melakukan kerjasama dengan LSM/CSO dari masing-masing negara ASEAN untuk melakukan konsultasi terhadap segala permasalahan HAM di tingkat regional.

Namun berdasarkan hasil penelitian, dalam progresnya untuk menjadi komisi HAM regional yang lebih baik AICHR 
masih mengalami beberapa hambatan. Terdapat 4 Faktor Penghambat AICHR dalam Penegakan Hak Asasi Manusia di Asia Tenggara, diantaranya prinsip ASEANWay dimana penggunaan prinsip non-intervensi dan kedaulatan negara ASEAN untuk hak asasi manusia yang masih belum fleksibel; Pengambilan Keputusan berdasarkan Konsensus yang membuat kinerja AICHR menjadi terhambat karena harus mendapat suara bulat dari seluruh negara anggota ASEAN; Lemahnya Mandat Fungsi Proteksi dalam ToR AICHR karena tidak tercapainya konsensus pada tahun 2010 ketika Indonesia mengajukan mandat perlindungan dasar untuk AICHR; adanya Kepentingan Politik dari Masing-masing Negara ASEAN seperti tidak dibahasnya suatu isu yang diangkat karena belum menjadi prioritas di negara tersebut serta tidak dibahasnya sebuah isu oleh suatu negara apabila isu tersebut bersifat sensitif pada rezim suatu negara. Adanya kepentingan politik dari negara anggota ASEAN juga mencakup Perbedaan Pandangan Masing-masing Negara ASEAN terhadap HAM dimana negara-negara ASEAN cenderung memandang HAM sebagai suatu permasalahan internal dan menganggap HAM adalah sebuah konsep barat, serta Komitmen Masing-masing Negara ASEAN terhadap HAM yang terkait dengan pelaksanaan instrumen-instrumen HAM yang belum sejalan sesuai dengan apa yang di ratifikasi dan terkait juga dengan independensi dari AICHR dimana perwakilan dari setiap negara ASEAN untuk AICHR belum sepenuhnya berasal dari non-pemerintahan. 


\section{Dinamika Global | Volume 02 | No.01 | Juni 2017}

Saran

Setelah melakukan penelitian mengenai Faktor-faktor Penghambat ASEAN Intergovernmental Commission on Human Rights (AICHR) Dalam Penegakan Hak Asasi Manusia di Asia Tenggara, terdapat beberapa saran dari peneliti diantaranya, penelitian ini menarik untuk dilanjutkan karena permasalahan dalam penelitian ini merupakan isu kontemporer dalam hubungan internasional khususnya terkait isu pelanggaran hak asasi manusia di Asia Tenggara yang semakin kompleks dengan munculnya banyak kejahatan dan permasalahan baru seiring dengan arus globalisasi yang terus meningkat. Bagi peneliti selanjutnya, permasalahan yang diangkat dalam skripsi ini menarik untuk dibahas dan diteliti lebih lanjut khususnya mengenai proses AICHR untuk menjadi komisi HAM regional yang lebih baik dengan segala permasalahan yang ada di dalamnya saat ini, terutama dalam mewujudkan mandatnya untuk melakukan fungsi proteksi bagi permasalahan HAM di tingkat regional.

Untuk saran peneliti bagi AICHR dalam mengatasi berbagai hambatan yang sedang dihadapi, diharapkan AICHR untuk melakukan amandemen terhadap ToRnya apabila hendak mempertahankan mandat untuk melakukan fungsi proteksi. AICHR diharapkan lebih terbuka kepada publik dengan setidaknya aktif untuk secara berkala melaporkan segala kegiatan AICHR secara rinci agar publik dapat lebih mengetahui eksistensi dan kinerja AICHR. AICHR juga diharapkan untuk setidaknya dapat memberikan respon terhadap segala kasus permasalahan HAM yang dilaporkan secara individual/kelompok walaupun memang belum terdapat mandat untuk melakukan penanganan berdasarkan laporan individual. Terkait dengan relasi antara AICHR dengan CSO, diharapkan AICHR semakin mempererat kerjasama yang sudah ada dengan CSO apabila 


\section{Dinamika Global | Volume 02 | No.01 | Juni 2017}

pada akhirnya mekanisme AICHR untuk melakukan fungsi proteksi akan dibantu oleh CSO/LSM masing-masing negara ASEAN. ASEAN dan AICHR juga diharapkan akan lebih fleksibel untuk menerapkan prinsip ASEANWay (Non-intervensi, kedaulatan dan konsensus) apabila terkait dengan permasalahan HAM demi terciptanya konsistensi dari implementasi berbagai konvensi HAM yang telah di ratifikasi oleh ASEAN itu sendiri. Untuk masing-masing perwakilan dari seluruh Negara ASEAN untuk AICHR juga diharapkan di masa yang akan datang dapat berasal dari akademisi/LSM yang dipilih melalui seleksi sehingga wakil tersebut betul-betul paham mengenai HAM demi terciptanya AICHR yang lebih baik.

Dan terakhir saran peneliti khususnya bagi AICHR Indonesia adalah tetap terus tingkatkan diplomasi antar masing-masing negara ASEAN untuk meningkatkan kesadaran negara-negara ASEAN terhadap pentingnya perlindungan HAM serta untuk meningkatkan komitmen mereka terhadap HAM dengan segala kewajiban yang harus dijalankan oleh masing-masing negara. 


\section{Dinamika Global | Volume 02 | No.01 | Juni 2017}

Daftar Pustaka

Acharya, Amitav. Constructing a Security Community in Southeast Asia: ASEAN and the Problem of Regional Order. London: Routledge, 2001.

Andrea Durbach, Catherine Renshaw and Andrew Byrnes. " $A$ tongue but no teeth"? The emergence of a regional human rights mechanism in the Asia-Pacific. (University of New South Wales Research Series: 2009.) 1

ASEAN Intergovernmental Commission On Human Rights (Terms of Reference).(23 Oktober 2009), internet. 7 September 2016.

http://www.asean.org/storage/images/archive/publications LTOR-of-AICHR.pdf

Bahder Johan Nasution. Negara Hukum dan Hak Asasi Manusia. Bandung: CVMandar Maju, 2011

Bauer, Joanne. "International Human Rights and Asian Commitment", HumanRights Dialogue, 1995).

Drummond, Catherine. "The ASEAN Intergovernmental Commission on HumanRights (AICHR) and the Responsibility to Protect: Development and Potential”, Australia: Asia Pacific Centre for R2P. Vol. 1, (2010). 5 


\section{Dinamika Global | Volume 02 | No.01 | Juni 2017}

Global Centre for the Responsibility to Protect. "About R2P”, Internet, 24

Februari 2017, http://www.globalr2p.org/about_r2p

History. "Rwanda: Background to Genocide". Internet. 13 desember 2016,

http://www.history.com/topics/rwandan-genocide

INFID. "Pernyataan INFID Menyambut Pertemuan Konsultasi Regional Komisi

HAM ASEAN (AICHR) dengan CSO Mengenai Review ToR AICHR", Jakarta (29 April 2014), internet, 25 Februari 2017, http://infid.org/pdfdo/1398830030.pdf hal.1

Kanis Dursin dalam Reporting ASEAN. "ASEAN Rights Body Sorely Lacks

Teeth - Critics" internet. 13 Desember 2016http://www.aseannews.net/asean-rights-body-sorelylacks-teeth-critics/

Kelsall, Michelle Staggs. "The New ASEAN Intergovernmental Commission on

Human Rights: Toothless Tiger or Tentative First Step". EastWest Center. No.90 (2009) 2

Keohane,Robert O. After Hegemony: Cooperation and Discord in the World 


\section{Dinamika Global | Volume 02 | No.01 | Juni 2017}

Political Economy. New Jersey: Princeton University Press, 1984.

Lamy, S.L. Contemporary Mainstrram Approaches: Neo-realism and $\mathrm{NeO}$

liberalism. In J. Baylis \& S. Smith, The Globalization of World Poltitics (Oxford. 2001) 190

Lidya Christin Sinaga. "Mengurai Peran Indonesia Dalam Penguatan AICHR."

Lembaga Ilmu Pengetahuan Indonesia, (13 Juni 2014), Internet. (Oktober 2016), http://www.politik.lipi.go.id/kolom/kolom$1 /$ politik-internasional/1000-mengurai-peran-indonesiadalam-penguatan-aichr

Rizka Meilinda. "Pengertian Rezim dan Teorinya". Web Fisip UNAIR. (09 Maret

2014). internet, 8 November 2016. http://rizka-meilindafisip13.web.unair.ac.id/artikel_detail-92823-RezimRezimInternasional-Pengertian-Rezim-dan-Teorinya.html

Rome Statute of The International Criminal Court, Article 5. Internet. 12

desember 2016 http://www.icc-cpi/nr/rdonlyres/ea9aeff75752-4f84-be94-0a655eb30e16/0/rome_statute_english.pdf

Sterling-folker, J. Neoliberalism. In T. Dunne, M. Kurki, \& S. Smith, 


\section{Dinamika Global | Volume 02 | No.01 | Juni 2017}

International Relations Theories. Oxford University Press: 2013.

Sugiyono. Metode Penelitian Kuantitatif Kualitatif dan R\&D. Bandung: Alfabeta,2014.

T. May Rudi. Administrasi \& Organisasi Internasional. Bandung: PT. Refika

Aditama, 2009.

TABLOID DIPLOMASI -. "Pelanggaran HAM diASEAN - AICHR Tidak

Diperbolehkan Melakukan Review". (Edisi Sabtu, 22 Mei 2010), Internet, 11 Januari 2017, http://www.tabloiddiplomasi.org/previous-isuue/90-mei2010/806-pelanggaran-ham-di-asean-aichr-tidakdiperbolehkan-melakukan-review.html

The Jakarta Post. "We Will Engage Civil Society Groups”. (11 Januari 2010),

Internet,

desember 2016 http://www.thejakartapost.com/news/2010/01/11/\%E2\% 80\%98we-will-engage-civil-society-groups $\%$ E2\% $80 \% 99 . \mathrm{html}$

United Nations - General Assembly. "2005 World Summit Outcome", $(15$

September 2005), internet, 24 Februari 2017, http://www.who.int/hiv/universalaccess2010/worldsummit .pdfParagraphs on the Responsibility to Protect (138-140) 


\section{Dinamika Global | Volume 02 | No.01 | Juni 2017}

Vienna Declaration and Programme of Action, paragraf 5 yang dikutip melalui

Human Rights: A Handbook For Parliamentarians, United Nations High Commissioner for Human Rights. hal.16

Vitit Muntarbhorn."A roadmap for an ASEAN Human Rights Mechanism".

Makalah dipresentasikan di $3^{\text {rd }}$ Workshop for an ASEAN Regional Mechanism on Human Rights. Bangkok, 28-29 Mei 2003. internet. 27 oktober 2016http://www.fnf.org.ph/liberallibrary/roadmap-forasean-human-rights.htm

Wahyudi Djafar, et al., Memperkuat Perlindungan Hak Asasi Manusia di

ASEAN. INFD dan ICCO, 2014. 